\title{
Elderly Satisfaction on Chronic Disease Management Program at Public Health Center, Bandung City, West Java, Indonesia
}

\author{
James Maladi Akbar, ${ }^{1}$ Sharon Gondodiputro, ${ }^{2}$ Ardini Saptaningsih Raksanagara ${ }^{2}$ \\ ${ }^{1}$ Faculty of Medicine Universitas Padjadjaran, Indonesia \\ ${ }^{2}$ Department of Public Health Faculty of Medicine Universitas Padjadjaran, Indonesia
}

\begin{abstract}
Objective: To identify the satisfaction level of the elderly on the health services provided by The Chronic Disease Management Program (prolanis) at the Public Health Center (puskesmas).
\end{abstract}

Methods: Adescriptive quantitative study with a cross-sectional approach had been carried out to 112 elderly from 8 puskesmas in Bandung City, West Java, Indonesia. This study was conducted from August until November 2019. The variables in this study were 5 dimensions of the

pISSN: 2302-1381; eISSN: 2338-4506; http://doi.org/10.15850/ ijihs.v8n1.1935 IJIHS. 2020;8(1):14-21

Received: January 9, 2020

Accepted: May 27, 2020 SERVQUAL. The collected data were analyzed using percentages and the Importance-Performance matrix.

Results: The satisfaction level of the elderly on the health services provided by the prolanis was $92 \%$. The dimension that has the highest satisfaction level was the assurance dimension $(94,6 \%)$ and the lowest one was the tangibles dimension $(84,8 \%)$. The result of the importanceperformance matrix showed that assurance, responsiveness, and empathy dimensions needed to be maintained to reach the patient's satisfaction.

Conclusions: The elderly satisfaction on the health services provided by the prolanis is high in every dimension of the SERVQUAL.

Keywords: Chronic disease management program, elderly, ImportancePerformance matrix, satisfaction, SERVQUAL

\section{Introduction}

Indonesia has an increase in the total population of the elderly. It is reported that in 2019 there was 25.64 million elderly in Indonesia $(9.60 \%)$ and this percentage is predicted to increase each year. ${ }^{1}$ The aging process causes the elderly more susceptible to disease. The overall morbidity rate both in urban and rural areas in three consecutive years from 2013 to 2015 was $24.8 \%, 25.05 \%$, and $28.62 \%$, respectively. Stroke, malignancy, asthma, and diabetes mellitus type 2 are the common diseases occurred. ${ }^{2}$ The Indonesian Social Security Agency in the health sector, developed a Chronic Disease Management Program (prolanis) for the National Health Insurance (JKN) participants, conducted especially at the public health center

Correspondence:

James Maladi Akbar,

Faculty of Medicine Universitas Padjadjaran, Indonesia

e-mail: maladiakbarjames@yahoo.co.id (puskesmas). The prolanis is a program that organized various activities to control the chronic diseases, prevent it from reaching complications, and finally increasing the health status of the elderly. ${ }^{3}$

The success of the prolanis is still not satisfactory. The compliance level is still low. ${ }^{4}$ The monitoring of the patient's blood sugar levels and the treatment compliance are not optimal. ${ }^{5}$ One of the causes of this low compliance is satisfaction. ${ }^{4}$

Patient satisfaction is one of the indicators of the quality of care. It indicates the success of the health providers to meet the patient's expectations of the health care they received. ${ }^{6}$ The satisfaction level can be measured through an instrument known as Service \& Quality (SERVQUAL).7,8 The study about the satisfaction level of the elderly on the prolanis by using SERVQUAL has not been carried out. Based on this information, the purpose of this study was to identify the satisfaction level of the elderly on the health services provided by the prolanis in the puskesmas. 


\section{Methods}

This study was a descriptive study with a cross-sectional method, conducted from August 2019 to November 2019 in Bandung City, West Java Indonesia. The total number of puskesmas that provided prolanis was 16 puskesmas and from that number, 50\% (8 puskesmas) were selected by simple random sampling. The inclusion criteria were elderly aged 60 years and over, willing to participate in the study, able to communicate well, and came for treatment at the puskesmas, whereas the exclusion criteria were elderly that did not take the interview completely. The total samples were calculated by using sample formula for categorical descriptive study, with $\alpha=5 \%$, and $p$ value $=0.88$. ${ }^{9}$ Based on that formula, the total samples needed in this study were 112 respondents. Before determining the number of elderly in each puskesmas, the researchers requested data on the presence of the elderly for 3 months in each selected puskesmas. This data was used as a denominator in calculating the number of samples in each puskesmas. The number of respondents in each puskesmas was calculated by the number of elderly visits at the puskesmas (n) divided by the total number of elderly visits to the 8 puskesmas $(\mathrm{N})$ and multiplied by the number of samples needed. On the day of data collection, the number of the elderly present was uncertain, therefore the respondents were selected using consecutive sampling, a sampling technique in which every subject meeting the criteria of inclusion was selected until the required sample size was achieved. Permission to do the study was obtained from three institutions, namely the Bandung City Mayor Office, Bandung City Health Office, and the selected puskesmas. This study had received the ethical clearance from the Health Research Ethics Committee of Universitas Padjadjaran Bandung, Indonesia under the ethical clearance 1036/UN6.KEP/ EC/2019.

The questionnaire of the SERVQUAL consisted of 22 statements and divided into 5 dimensions, namely tangibles, reliability, assurance, responsiveness, and empathy ${ }^{7,8}$, and was developed by the Departement of Public Health Faculty of Medicine Universitas Padjadjaran in 2011, based on the SERVQUAL by Parasuraman. It was tested to 53 respondents from Bandung City. A content and construct analysis were carried out. The result of the Cronbach's alpha was between 0,801 and 0,977 for each dimension. ${ }^{10}$ The tangibles dimension consisted of 4 statements, namely visually appealing rooms; complete facilities; employees who have a neat, professional appearance; and complete medical equipment. The reliability dimension consists of 5 statements, namely, providing services as promised; dependability in handling customers' problems; simple procedures; providing services at the promised time; and prompt administrative services. The assurance dimension consisted of 4 statements, namely health providers who instill confidence in customers; making customers feel safe; respect the customers; and health providers who have the knowledge to answer customer questions. The responsiveness dimension consisted of 4 statements, namely keeping customers informed about when services will be performed; prompt service to customers; willingness to help the customers; and readiness to respond to customers' requests. The empathy dimension consisted of 5 statements, namely giving customers individual attention without any discrimination; convenient business hours; health providers who understand the needs of their customers; having the customer's best interest at heart; and health providers who deal with customers in a caring fashion. ${ }^{10}$ Each statement had two columns namely "expectation" and "reality" columns that had a score ranging from 1 to 10 . Prior to data collection, the selected respondents were given explained about the purpose and procedure of the study. After they understood and agreed to participate in this study, they signed the informed consent form. The researcher read and explained the meaning of each statement one by one to the respondents and the respondents chose the right score for each statement both for the "expectation" and "reality" aspects.

The average score of the "expectation" and the "reality" was calculated by adding up the total score of "expectation" or "reality" divided by the number of samples. The satisfaction level was calculated by dividing the "reality" average score with the "expectation" average score and multiplied by $100 \%$. Satisfied if the percentage reached $\geq 80 \%$, and dissatisfied if the percentage was $<80 \%{ }^{11}$

The collected data were statistically analyzed using Fisher's exact test or Kolmogorov-Smirnov test to identify the difference of satisfaction according to the characteristics of the respondents.

The importance and performance matrix had 2 components, those were the $x$-axis (performance/reality axis) and the y-axis 


\begin{tabular}{l|l} 
Main Priority (I) & $\begin{array}{l}\text { Maintain Achievement } \\
\text { (II) }\end{array}$ \\
& \\
\hline Low Priority (III) & Overload (IV) \\
&
\end{tabular}

Figure 1 Importance-Performance Matrix

(importance/expectation axis)..$^{12}$ The value of the $\mathrm{x}$-axis was the "reality" average score and the value of the y-axis was the "expectation" average score. ${ }^{12}$ This matrix created using IMB SPSS 22.0. Both axes create a Cartesian diagram that had four quadrants. (Figure 1).

Quadrant I showed customers feel that the health services provided by the prolanis was high, but the performance was low. The quality of health services that entered this quadrant should be prioritized to be improved because of the high importance and low satisfaction. Quadrant II showed the area in which health services at the prolanis needed to be maintained to make sure that the customers were still satisfied with the health services provided because the level of importance and performance were both high. Quadrant III showed a low priority area because of the low importance and low performance. The performance of the prolanis was low, and the importance perceived by the customer was also low. This situation did not mean that the organization did not have to enhance the quality of their services. They still had to provide health care better than before. Quadrant IV was categorized as overload area because there were factors that were not important for consumers (low importance level), but the organization provided the health care with a high performance. ${ }^{12,13}$

\section{Results}

The study on the satisfaction level of the elderly on the health care provided by the prolanis in Bandung City has been conducted using SERVQUAL questionnaires with total respondents of 112 elderly. Table 1 showed

Table 1 Respondent's Characteristics and Satisfaction

\begin{tabular}{|c|c|c|c|c|}
\hline Characteristic & $\begin{array}{c}\text { Frequency } \\
(n=112)(\%)\end{array}$ & $\begin{array}{c}\text { Dissatisfied } \\
(n=9)(\%)\end{array}$ & $\begin{array}{c}\text { Satisfied } \\
(n=103)(\%)\end{array}$ & p-value \\
\hline $\begin{array}{l}\text { Age (years old) } \\
\quad 60-69 \\
>70\end{array}$ & $\begin{array}{l}70(62.5) \\
42(37.5)\end{array}$ & $\begin{array}{l}3(4.3) \\
6(14.3)\end{array}$ & $\begin{array}{l}67(95.7) \\
36(85.7)\end{array}$ & $0.078 *$ \\
\hline $\begin{array}{l}\text { Education } \\
\leq \text { Elementary School } \\
\text { Junior high school } \\
\text { Senior high school } \\
>\text { Senior high school }\end{array}$ & $\begin{array}{l}44(39.3) \\
26(23.2) \\
27(24.1) \\
15(13.4)\end{array}$ & $\begin{array}{l}3(6.8) \\
2(7.7) \\
1(3.7) \\
3(20.0)\end{array}$ & $\begin{array}{l}41(93.2) \\
24(92.3) \\
26(96.3) \\
12(80.0)\end{array}$ & $0.831^{* *}$ \\
\hline $\begin{array}{l}\text { Marital status } \\
\text { Not married } \\
\text { Married } \\
\text { Divorce }\end{array}$ & $\begin{array}{l}1(0.9) \\
60(53.6) \\
51(45.5)\end{array}$ & $\begin{array}{l}0(0.0) \\
5(8.3) \\
4(7.8)\end{array}$ & $\begin{array}{l}1(100) \\
55(91.7) \\
47(92.2)\end{array}$ & $1.000^{* *}$ \\
\hline $\begin{array}{l}\text { Occupation } \\
\text { Retired } \\
\text { Employed }\end{array}$ & $\begin{array}{l}88(78.6) \\
24(21.4)\end{array}$ & $\begin{array}{c}6(6.8) \\
3(12.5)\end{array}$ & $\begin{array}{l}82(93.2) \\
21(87.5)\end{array}$ & $0.400^{*}$ \\
\hline $\begin{array}{l}\text { Disease } \\
\text { Hypertension } \\
\text { Diabetes mellitus } \\
\text { Hypertension and Diabetes mellitus }\end{array}$ & $\begin{array}{l}49(43.8) \\
34(30.4) \\
29(25.9)\end{array}$ & $\begin{array}{l}5(10.2) \\
0(0.0) \\
4(13.8)\end{array}$ & $\begin{array}{l}44(89.4) \\
34(100) \\
25(86.2)\end{array}$ & $0.889 * *$ \\
\hline
\end{tabular}

Notes: *Fisher's exact test; ** Kolmogorov-Smirnov test 


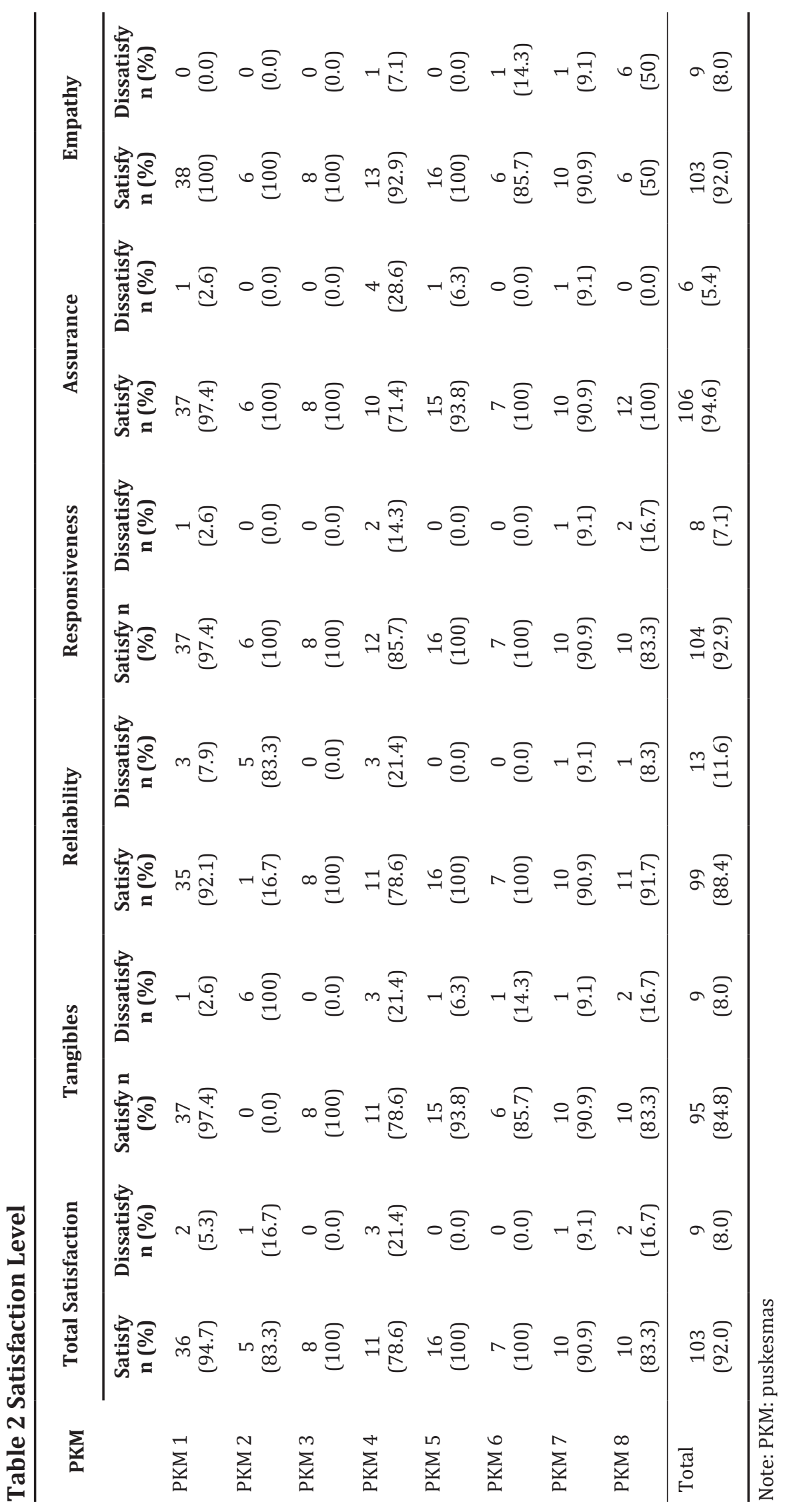




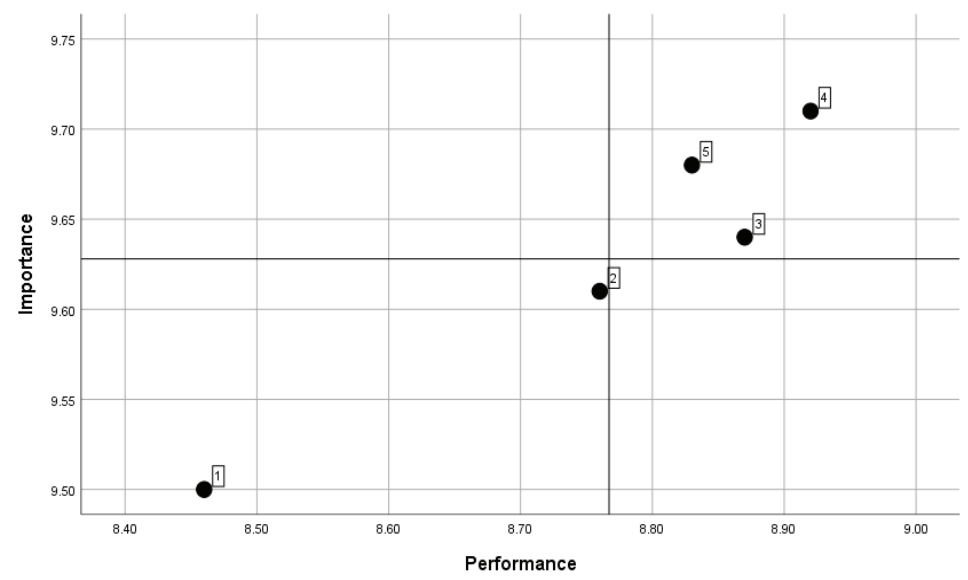

Figure 2 Importance-Performance Matrix for 5 Dimensions of Satisfaction

Notes: 1 . Tangibles; 2. Reliability; 3. Responsiveness; 4. Assurance; 5.Empathy

that most of the respondents were aged 60-69 years old, low education, married, retired, and had hypertension. There was no difference in satisfaction level satisfaction for all characteristic variables ( $\mathrm{p}$-value $\geq 0.05$ ).

This study discovered that the satisfaction level was very high. The dimension that had the highest satisfaction level was the assurance dimension $(94,6 \%)$ and the lowest was the tangibles dimension $(84,8 \%$; Table 2$)$.

This study revealed that there were differences in the total satisfaction and in every dimension that existed in the eight puskesmas. In the puskesmas number 2 , the total satisfaction was high, but in the tangibles and reliability dimensions, the satisfaction was low. Puskesmas number 4 had the lowest level of satisfaction compared to the other puskesmas (Table 2).

This study discovered that tangibles and reliability dimensions placed inside the quadrant III, which means that both dimensions had a low priority to be improved, while assurance, responsiveness, and empathy dimensions placed inside the quadrant II which means the health providers needed to maintain the health service quality in these three dimensions (Figure 2).

Every statement in every dimension was plotted also into the Importance-Performance Matrix. This study discovered that "the complete medical equipment" statement (tangibles) placed in the first quadrant. Moreover, the "simple procedures" statement

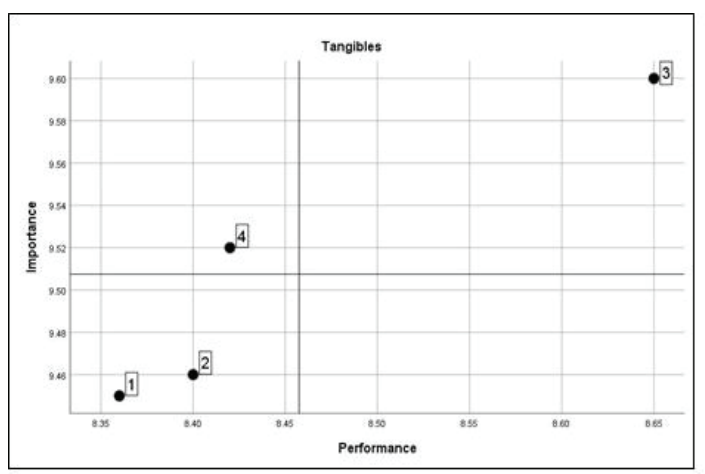

1 .visually appealing rooms; 2 . complete facilities; 3.employees who have a neat, professional appearance, 4.complete medical equipment

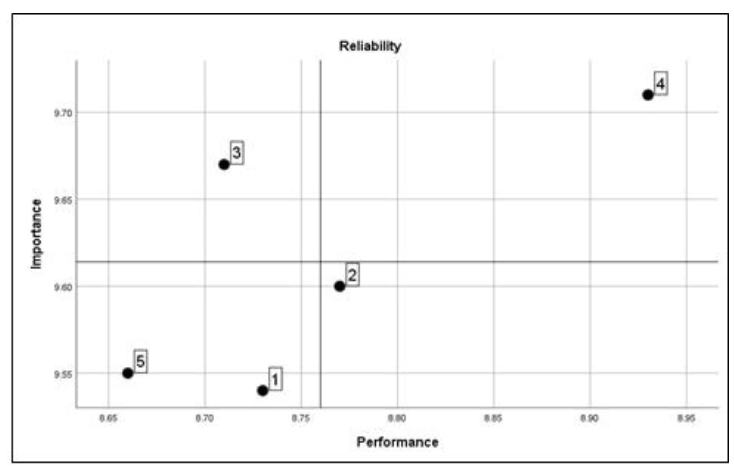

1.providing services as promised; 2 dependability in handling customers' problems; 3 simple procedures; 4 .providing services at the promised time; 5 . prompt administrative services.

Figure 3 Tangibles and Reliability Importance-Performance Matrix 


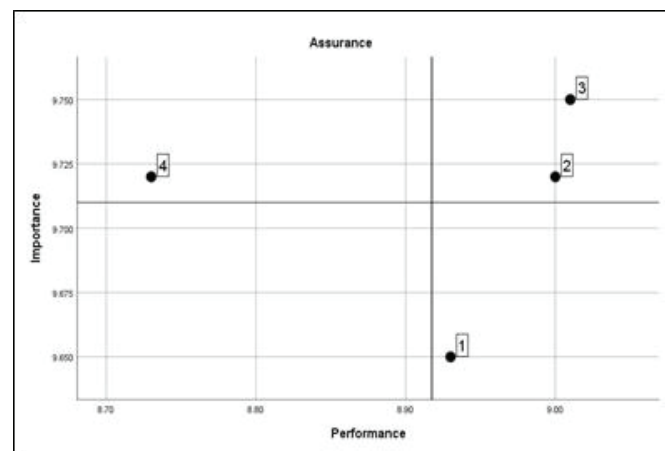

1.health providers who instill confidence in customers; 2. making customers feel safe; 3 . respect the customers; 4 . health providers who have the knowledge to answer customer questions

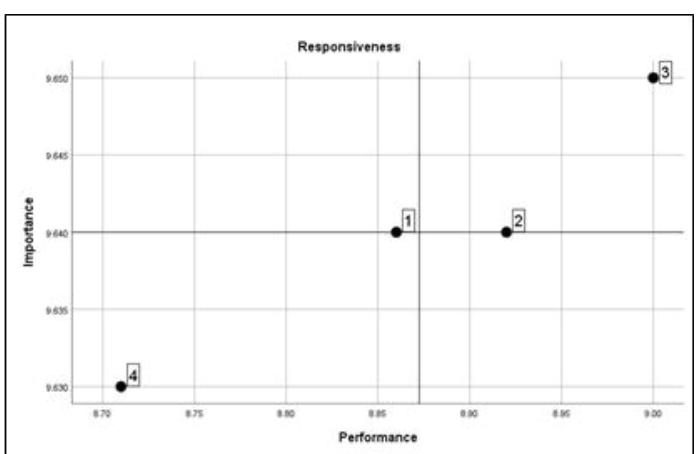

1.keeping customers informed about when services will be performed; 2.prompt service to customers;

3 willingness to help the customers; 4 .readiness to respond to customers' requests

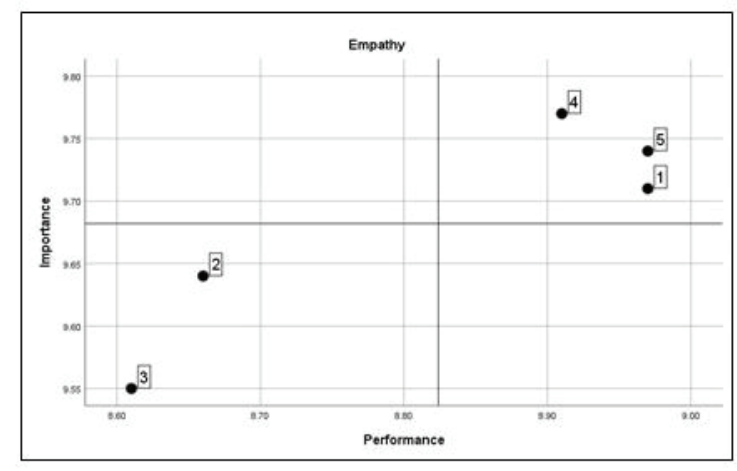

1. giving customers individual attention without any discrimination; 2 . convenient business hours; 3 . health providers who understand the needs of their customers: 4 . having the customer's best interest at heart; 5 . health providers who deal with customers in a caring fashion

Figure 4 Assurance, Responsiveness, and Empathy Importance-Performance Matrix

(reliability) placed in the first quadrant as well (Figure 3).

Regarding the assurance dimension, this study discovered that the statement about "health providers who knew to answer customer questions" placed in the first quadrant (Figure 4).

\section{Discussion}

Prolanis is a health service system that involves patients, as members of the JKN, primary health facilities, and The Indonesian Social Security Agency in the health sector, who suffer from chronic diseases, especially hypertension and diabetes mellitus. Six prolanis activities consist of: (1) medical consultation; (2) health education; (3) SMS gateway reminder; (4) home visit; (5) physical exercise (gymnastics) and;
(6) monitoring health status. ${ }^{3}$ The goal of the prolanis is to encourage participants to come to the puskesmas for monitoring and treating their diseases so that they achieve optimal quality of life and prevent complications. ${ }^{3}$

Patient satisfaction is one of the indicators for measuring the quality of health care services. Measuring the level of satisfaction is very important as satisfaction might affect adherence to treatment for chronic diseases such as hypertension and diabetes mellitus. ${ }^{14}$ Moreover, assessing the level of satisfaction can give information on whether the services provided by the puskesmas are in accordance with the customer expectation. ${ }^{6}$ This study discovered that most of the respondents were satisfied with the health services provided at the prolanis in every dimension, however, the tangible dimension had the lowest satisfaction 
level compared to the other dimensions of SERVQUAL. Moreover, the responsiveness, assurance, and empathy dimensions placed in the Quadrant II of the importance-performance matrix which means that the quality of those dimensions should be maintained. . $^{12,13}$

From the tangible dimension, the main component that needed to be improved is the availability of medical equipment such as the insulin syringe. In Indonesia, hypertension and diabetes mellitus are chronic diseases that have become the primary concern for the public health sector. ${ }^{15}$ The hypertension prevalence in Indonesia is quite high as many as $8.6-10 \%{ }^{16}$, while the diabetes prevalence is as many as $4,6 \%{ }^{17}$ The management of hypertension and diabetes without complications is the authority of doctors who work at the puskesmas, therefore the availability of medicines and insulin syringes need to be considered.

The reliability dimension placed inside the quadrant III of the importance-performance matrix which means that this dimension had a low priority to be improved, however, there is one component of the reliability dimension that should be improved, namely the procedures at the prolanis was complicated, not a simple one, especially when the puskesmas referred them to the hospital. This is in accordance with the study by Nurheda et al., that the respondents were not satisfied because they had not been served promptly and tended to be convoluted..$^{18}$

The ability of the health providers to answer the patients' questions is a component of the assurance dimension placed in the quadrant I. A study conducted by Andrew H. Van de Ven et al discovered that patients will feel satisfied if the health providers were able to explain about the condition of illness, the treatment given and the side effects of the medicine given to the patients. ${ }^{19}$

\section{References}

1. BPS-Statistics Indonesia. Statistik penduduk lanjut usia 2019. Jakarta; 2019.

2. Indonesian Ministry of Health. Riset kesehatan dasar 2018. Jakarta: Badan Penelitian dan Pengembangan Kesehatan Kemenkes RI; 2018.

3. Rosdiana AI. Implementasi program pengelolaan penyakit kronis (Prolanis). Higeia J Public Heal Res Dev. 2017;1(3):140-50.

4. Asfiani LV, Ilyas Y. Level of adherence and its determinants of Prolanis attendance in type
This study discovered that tangible and reliability dimension, and several components in other dimensions placed inside the quadrant III. This quadrant described that the respondents had a low expectation and the performance of the health care provided at the prolanis was low. ${ }^{13}$ the purpose of this paper is to measure service quality provided to surgical and medical inpatients at Kerman Medical Sciences University (KUMS Compared to other quadrant, dimensions or statements placed in this quadrant showed a low priority to be intervened. ${ }^{12,13}$ Sanam Roder-DeWan et al. stated that the low expectation of the patients, made them feel satisfied with the low quality of the health services. There was no demand to improve the quality of the health services and in the end the health providers will not make efforts to enhance the quality of their health services. ${ }^{20}$

This study has some limitations. This study did not link the satisfaction level with treatment adherence. There were lots of statements in the SERVQUAL questionnaire that require a considerable amount of time to answer by the respondents. This causes some of the elderly were suspected of not answering them in accordance with their choices.

The conclusion of this study is the satisfaction level of the elderly on the health care provided at the prolanis is high. The dimension with the highest satisfaction level is the assurance dimension $(94,6 \%)$ and the lowest in the tangibles dimension (84,8\%). The responsiveness, assurance, and empathy dimensions should be maintained so that the elderly satisfied with the health care provided, however, some of the components of tangible and reliability dimensions should be improved. Further study needed to be conducted to analyze the relationship between satisfaction level and the treatment adherence of patients with hypertension and diabetes.

2 Diabetes Mellitus participants at five BPJS primary health care in Bekasi 2016. J Indones Heal Policy Adm. 2017;2(2):6-13.

5. Raraswati A, Heryaman H, Soetedjo NNM. Peran program Prolanis dalam penurunan kadar gula darah puasa pada pasien Diabetes Melitus tipe 2 di Puskesmas Kecamatan Jatinangor. J Sist Kesehat. 2018;4(2):65-70.

6. Xesfingi S, Vozikis A. Patient satisfaction with the healthcare system: Assessing the impact 
of socio-economic and healthcare provision factors. BMC Health Serv Res. 2016;16(1):1-7.

7. Sari DP, Harmawan A. Usulan perbaikan kualitas pelayanan pada instalasi rawat jalan dengan metode SERVQUAL dan TRIZ. J Tek Ind. 2012;95-6.

8. Rinnasa P-A, Nababan ESM, Bu'ulolo F. Strategi peningkatan kualitas pelayanan kesehatan menggunakan integrasi metode Fuzzy Servqual. Saintia Mat. 2013;1(6):529-41.

9. Oktavia D. Gambaran tingkat kepuasan dan harapan pasien pada pelayanan program pengelolaan penyakit kronis (PROLANIS) di wilayah kerja Puskesmas Kalimanah Purbalingga. [Thesis]; 2018.

10. Rinawan FR, Djuhaeni H, Arisanti N, Gondodiputro S, Pudjisetiawati E, Wiwaha G, et al. Kajian kepuasan pasien terhadap kualitas layanan PPK Primer Kota Bandung. Bandung: Dinas Kesehatan Kota Bandung; 2011.

11. Rajbanshi L, Dungana G, Gurung Y, Koirala D. Satisfaction with health care services of out patient department at Chitwan Medical College Teaching Hospital, Nepal. J Chitwan Med Coll. 2014;4(7):11-2.

12. Gonçalves JR, Pinto A, Batista MJ, Pereira AC, Bovi Ambrosano GM. Importance-performance analysis: Revisiting a tool for the evaluation of clinical services. SciRes. 2014;06(05):285-91.

13. Izadi A, Jahani Y, Rafiei S, Masoud A, Vali L. Evaluating health service quality: using importance performance analysis. Int J Health Care Qual Assur. 2017;30(7):1-9.
14. Bakar ZA, Fahrni ML, Khan TM. Patient satisfaction and medication adherence assessment amongst patients at the diabetes medication therapy adherence clinic. Diabetes Metab Syndr Clin Res Rev. 2016;10(2):1-17.

15. Dyanneza F, Tamtomo DS. The Effectiveness of chronic disease management program in blood pressure control among hypertensive patients. Indones J Med. 2017;2(1):52-62.

16. Syahrini EN, Susanto HS, Udiyono A. Faktorfaktor risiko hipertensi primer di Puskesmas Tlogosari Kulon Kota Semarang. J Kesehat Masy. 2012;1(2):315-25.

17. Mihardja L, Soetrisno U, Soegondo S. Prevalence and clinical profile of diabetes mellitus in productive aged urban Indonesians. J Diabetes Investig. 2014;5(5):507-12.

18. Nurheda, Usman, Rusman ADP. Hubungan kualitas pelayanan kesehatan dengan kepuasan pasien pengguna Badan Penyelenggara Jaminan Sosial (BPJS) di Puskesmas Maiwa Kabupaten Enrekang. J Ilm Mns dan Kesehat. 2018;1(3):201-16.

19. Van de Ven AH. What matters most to patients? Participative provider care and staff courtesy. Patient Exp J. 2014;1(1):131-9.

20. Roder-DeWan S, Gage AD, Hirschhorn LR, Twum-Danso NAY, Liljestrand J, AsanteShongwe K, et al. Expectations of healthcare quality: A cross-sectional study of internet users in 12 low- and middle-income countries. PLOS Med. 2019;16(8):e1002879. 